\title{
Exploring Students' Ability and Problems in Writing Opinion Column Piece
}

\author{
Taufik Afdal ${ }^{1}$ \\ ${ }^{1}$ Corresponding author, English Education Department, STAI Miftahul Ulum, Tanjung pinang, Indonesia \\ $\underline{\text { taufikafdaltranslator@gmail.com }}$
}

Received: June 6, 2020 Accepted: Desember 12, 2020

Published: January 20, 2021

\begin{abstract}
The aims of this study are twofold. Firstly, it aims to explore English Education Department, STAI Miftahul Ulum Tanjungpinang students' ability in writing opinion column piece. Secondly, it aims to investigate the problems faced by students when writing opinion column piece. A total of 10 students participated in this study. The research took place in January 2020. An essay test and a semi-structured interview were used to collect the data. The data were further analyzed using content analysis where the researcher scrutinized students' works after they were given the task of completing an opinion column piece writing. In order to classify students' ability, we adopted five indicators of writing opinion piece, namely focus, ethos, pathos, logos and research and writing fluency. The study lead to the findings that from the total of ten students, seven students fell under the category of average, three students fell under the category of good. Furthermore, most students expressed that generating ideas are difficult. The problems students faced and their detailed score are further elaborated on the paper.
\end{abstract}

Keywords: English Education Students; Newspaper Opinion; Writing Analysis

To cite this article: Afdal, T. (2021). Exploring students' ability and problems in writing opinion column piece. SALEE: Study of Applied Linguistics and English Education, 2(01), 1-9. https://doi.org/10.35961/salee.v2i01.118

DOI: $10.35961 /$ salee.v2i01.118

\section{Introduction}

At the University level, having a good writing skill is mandatory for every student especially those taking an English Education major. This is because almost every task 
completed by the students must be in the form of written documents, for example, papers, articles, reports assignments, final projects, and thesis. Yet, writing remains a major problem faced by EFL learners, not only in Indonesia, since it requires much time and effort (Belkhir, Benyelles, 2017:80). Among other writing modes, opinion essay is one type of writing which is oftenly used for the college writing.

For most Indonesian EFL learners, writing has become an issue. Based on the observation throughout the semester at the locus of the study, a number of factors might be the causing factors, including the use of grammar, the use of punctuation, the use of capitalization, the use of article, logical connectors, subject-verb agreement, the flow of the writing, the choice of words, the mistranslation of certain terminologies, etc. This is the job of every lecturer to deliver good quality of teaching writing to the students. Innovation is thus required to motivate students to write better in English.

As one of the departments, English Education Department of STAI Miftahul Ulum Tanjungpinang has four competences for students to master by the end of their study terms, namely English Teacher, Translator, Tourism Workers, and Journalist. Therefore, this study is reflected upon students' ability in writing English opinion column piece which is one of the types of journalistic writing.

\subsection{Research Question}

Based on the problems above, the researcher formulated the problem as:

1. How is students' ability in writing opinion piece?

2. What problems did students face when writing an opinion piece?

\subsection{Theoretical Framework}

\subsubsection{Opinion Piece}

An opinion piece is an article published in a newspaper or magazine featured in many periodicals mainly reflecting the author's opinion about a subject (Opinion Piece: 2020). Similar to the concept of an opinion essay, opinion piece also tells what the writer thinks or feels about a topic.

Since opinion in a column piece should attract readers, the product of an opinion should be of interest to the readers. Classical rhetoricians analyzed the ways that effective speeches persuaded their audiences which include logos, ethos, and pathos. (Roen, D., et. al., 2011:20)

Logos, derived from Greek which means 'word', looks at the quality of the message such as consistency in the writing and clarity of the argument and the logic of its reasons and support. Ethos, also derived from Greek which means 'character', refers to the credibility of the writer. Ethos is often conveyed through the writer's investment in his or her claim, through the fairness with which the writer considers alternative views, through the tone and style of the message, and include the correct use of grammar, immaculate proofreading, and appropriate formats for citations and bibliography. In some cases, ethos is also a function of the writer's reputation for honesty and expertise independent of the message. While pathos, from the Greek word which means 'suffering' or 'experience', looks at the values and beliefs of the intended audience. It is often related to the emotional appeal more specifically to an audience's imaginative sympathies, their capacity to feel and see what the writer feels and sees. Ramage (2016) added that besides these three concepts in persuasive appeals, there is 
another term that could be added, namely, kairos, derived from Greek meaning "right time," "season," or "opportunity." This concept suggests that for an argument to be persuasive, its timing must be effectively chosen and its tone and structure in right proportion or measure. Another aspect that is also important in writing an opinion piece is focus. "Finding Your Focus" (n.d.) describes focus as the controlling idea, main point, or guiding principle of your writing. It has a very clear focus with secondary and related ideas positioned in order to supplement or support it. "Finding Your Focus" (n.d.) added that focus cannot be gained through a once process, but rather a result of exploration, drafting, and revision.

\section{Method}

This study applied a content analysis method. The researcher analyzed students' work to investigate their quality. Prior to assigning students with writing an opinion piece, the researcher explained the aspects of writing an opinion column piece in the first meeting. In the second meeting, the researchers assigned them with task of writing an opinion piece with an updated and current topic in not more than 300 words in ninety minutes. The subjects in this study were 10 tudents of seventh semester of English Education Department of STAI Miftahul Ulum Tanjungpinang aged from 20 to 24 in 2019-2020 academic year. These students have studied the course of English for Journalism and they were taught how to write different types of news articles. In order to collect students' writing, we used a test in the form of writing an opinion column piece in not more that 250 words and a semi-structured interview with five questions. To know the students' score in writing opinion news, the reseacher used an analytic scoring rubric adopted from studylib.net.

The analytic scoring rubric has some categories, including A with the highest score and $\mathrm{F}$ with the lowest score. If the total score is 20 in one category, for example of focus, then it was divided by five, which means that the highest score is 20 , the second highest is 16 , the middle score is 12 , the second lowest is 8 , and the lowest score is 4 . While if the total score is 25 in one category, for example of pathos, then it was also divided by five, which means that the highest score is 25 , the second highest is 20 , the middle score is 15 , the second lowest is 10 , and the lowest score is 5 . Thereby, we could classify their ability by referring to the description of each score classification as presented in table 1 below.

Table 1: Scoring Rubric Assessment Rubric for Opinion Piece

\begin{tabular}{clllll}
\hline Category & \multicolumn{1}{c}{$\mathbf{A}$} & \multicolumn{1}{c}{ B } & \multicolumn{1}{c}{ C } & \multicolumn{1}{c}{ D } \\
\hline & Response & Response may & Response may & Response may & Response \\
Focus & maintains & exhibit minor & lose or may & fail to establish & lacks focus. \\
20 pts. & focus on & lapses in focus & exhibit major & focus on & \\
& topic/subject & on & lapses in focus & topic/subject. & \\
& throughout & topic/subject. & on topic/subject. & & \\
& response. & & & & \\
\hline
\end{tabular}




\begin{tabular}{|c|c|c|c|c|c|}
\hline $\begin{array}{l}\text { Ethos: } \\
15 \text { pts. }\end{array}$ & $\begin{array}{l}\text { The writer } \\
\text { uses strong } \\
\text { arguments } \\
\text { and } \\
\text { introduces } \\
\text { evidence to } \\
\text { show high } \\
\text { quality } \\
\text { sources. }\end{array}$ & $\begin{array}{l}\text { Most of the } \\
\text { writer's } \\
\text { arguments and } \\
\text { evidence is } \\
\text { strong. Quality } \\
\text { of sources is } \\
\text { evident. }\end{array}$ & $\begin{array}{l}\text { The writer's } \\
\text { arguments and } \\
\text { evidence are } \\
\text { uneven in } \\
\text { quality, though } \\
\text { overall they are } \\
\text { adequate. Sourc } \\
\text { e quality } \\
\text { appears } \\
\text { questionable. }\end{array}$ & $\begin{array}{l}\text { One or more of } \\
\text { the writer's } \\
\text { arguments and } \\
\text { evidence is } \\
\text { significantly } \\
\text { weak. Source } \\
\text { quality appears } \\
\text { poor. }\end{array}$ & $\begin{array}{l}\text { The writer } \\
\text { did not use } \\
\text { any effective } \\
\text { arguments or } \\
\text { evidence. } \\
\text { Source } \\
\text { quality is } \\
\text { poor or } \\
\text { unknown. }\end{array}$ \\
\hline $\begin{array}{c}\text { Pathos: } \\
15 \text { pts. }\end{array}$ & $\begin{array}{l}\text { The writer } \\
\text { uses } \\
\text { effective } \\
\text { strategies to } \\
\text { appeal to the } \\
\text { reader's } \\
\text { values and } \\
\text { beliefs. }\end{array}$ & $\begin{array}{l}\text { Most of the } \\
\text { writer's } \\
\text { appeals to the } \\
\text { readers' values } \\
\text { and beliefs are } \\
\text { effective. }\end{array}$ & $\begin{array}{l}\text { The writer's } \\
\text { appeals to the } \\
\text { readers' values } \\
\text { and beliefs are } \\
\text { uneven, though } \\
\text { overall they are } \\
\text { adequate. }\end{array}$ & $\begin{array}{l}\text { One or more of } \\
\text { the writer's } \\
\text { appeals to the } \\
\text { readers' values } \\
\text { and beliefs are } \\
\text { significantly } \\
\text { inadequate. }\end{array}$ & $\begin{array}{l}\text { The writer } \\
\text { did not use } \\
\text { any effective } \\
\text { appeals to } \\
\text { the readers' } \\
\text { values and } \\
\text { beliefs. }\end{array}$ \\
\hline $\begin{array}{l}\text { Logos and } \\
\text { Research: } \\
25 \text { pts. }\end{array}$ & $\begin{array}{l}\text { The writer's } \\
\text { organization } \\
\text { and logic is } \\
\text { strong. } \\
\text { Research } \\
\text { effectively } \\
\text { supports the } \\
\text { argument } \\
\text { and is } \\
\text { correctly } \\
\text { cited, both } \\
\text { in-text and } \\
\text { on Reference } \\
\text { page or } \\
\text { notes. }\end{array}$ & $\begin{array}{l}\text { Most of the } \\
\text { writer's } \\
\text { organization } \\
\text { and logic is } \\
\text { strong. Most } \\
\text { of the research } \\
\text { supports the } \\
\text { argument and } \\
\text { is correctly } \\
\text { cited both in- } \\
\text { text and on } \\
\text { Reference } \\
\text { page or notes. }\end{array}$ & $\begin{array}{l}\text { The writer's } \\
\text { organization and } \\
\text { logic is uneven, } \\
\text { though overall } \\
\text { they are } \\
\text { adequate. The } \\
\text { research is } \\
\text { uneven in } \\
\text { quality, though } \\
\text { overall it is } \\
\text { adequate, and it } \\
\text { is mostly } \\
\text { correctly cited } \\
\text { both in-text and } \\
\text { on Reference } \\
\text { page or notes. }\end{array}$ & $\begin{array}{l}\text { The writer has } \\
\text { at least one } \\
\text { major problem } \\
\text { with } \\
\text { organization } \\
\text { and/or logic. } \\
\text { Significant } \\
\text { portion of } \\
\text { research fails to } \\
\text { support the } \\
\text { argument and/or } \\
\text { is incorrectly } \\
\text { cited either in- } \\
\text { text and on } \\
\text { Reference page } \\
\text { or notes. }\end{array}$ & $\begin{array}{l}\text { The writer } \\
\text { did not use } \\
\text { effective } \\
\text { organization } \\
\text { and/or logic. } \\
\text { No research } \\
\text { and/or fails } \\
\text { to support } \\
\text { the argument } \\
\text { and/or is } \\
\text { incorrectly } \\
\text { cited either } \\
\text { in-text or on } \\
\text { Reference } \\
\text { page or } \\
\text { notes. }\end{array}$ \\
\hline $\begin{array}{l}\text { Writing } \\
\text { Fluency: } 2 \\
5 \text { pts. }\end{array}$ & $\begin{array}{l}\text { There are } \\
\text { few, if any, } \\
\text { errors. } \\
\text { Writing is } \\
\text { clear and } \\
\text { concise. }\end{array}$ & $\begin{array}{l}\text { There are a } \\
\text { few surface } \\
\text { errors but they } \\
\text { are not } \\
\text { distracting. } \\
\text { Writing is } \\
\text { clear and } \\
\text { concise. }\end{array}$ & $\begin{array}{l}\text { Some surface } \\
\text { errors are } \\
\text { distracting, } \\
\text { though they } \\
\text { don't impede } \\
\text { overall } \\
\text { communication. } \\
\text { Writing is } \\
\text { mostly clear } \\
\text { and/or a bit } \\
\text { wordy. }\end{array}$ & $\begin{array}{l}\text { Surface errors } \\
\text { sometimes make } \\
\text { it difficult to } \\
\text { understand the } \\
\text { writer's } \\
\text { message. } \\
\text { Writing is } \\
\text { generally } \\
\text { unclear and/or } \\
\text { wordy. }\end{array}$ & $\begin{array}{l}\text { Surface } \\
\text { errors make } \\
\text { it very } \\
\text { difficult to } \\
\text { understand } \\
\text { the writer's } \\
\text { message. } \\
\text { Writing is } \\
\text { unclear } \\
\text { and/or } \\
\text { wordy. }\end{array}$ \\
\hline
\end{tabular}


To determine and analyze students' ability, the researcher used the students' score skill level (table 2). There are five level of the students' writing ability encompassing poor, fair, average, fairly good, and good.

Table 2: The students' score skill level

\begin{tabular}{cc}
\hline Score Interval & Classification \\
\hline $81-100$ & Good \\
\hline $61-80$ & Fairly Good \\
\hline $41-60$ & Average \\
\hline $21-40$ & Fair \\
\hline $0-20$ & Poor \\
\hline
\end{tabular}

\section{Finding and Discussion}

Presented below is the overall students' scores based on each indicator of opinion piece, namely: focus, ethos, pathos, logos and research, and writing fluency.

Table 3: Recapitulation of Students' Overall Score

\begin{tabular}{|c|c|c|c|c|c|c|c|c|}
\hline \multirow{3}{*}{ Student } & \multirow{3}{*}{ Category } & \multirow{3}{*}{ Score } & \multicolumn{5}{|c|}{ Category } & \multirow[b]{2}{*}{$\begin{array}{l}\text { Total } \\
\text { Score }\end{array}$} \\
\hline & & & Focus & Ethos & Pathos & $\begin{array}{c}\text { Logos } \\
\text { and } \\
\text { Research }\end{array}$ & $\begin{array}{l}\text { Writing } \\
\text { Fluency }\end{array}$ & \\
\hline & & & $(<20)$ & $(<15)$ & $(<15)$ & $(<25)$ & $(<25)$ & $(\%)$ \\
\hline 1 & Good & B & 18 & 12 & 10 & 15 & 20 & 75 \\
\hline 2 & Average & $\mathrm{C}$ & 10 & 10 & 7 & 10 & 15 & 52 \\
\hline 3 & Average & $\mathrm{C}$ & 9 & 9 & 5 & 10 & 15 & 48 \\
\hline 4 & Average & $\mathrm{C}$ & 10 & 8 & 7 & 10 & 18 & 53 \\
\hline 5 & Average & $\mathrm{C}$ & 9 & 7 & 7 & 10 & 15 & 48 \\
\hline 6 & Good & A & 13 & 12 & 10 & 23 & 18 & 76 \\
\hline 7 & Good & B & 10 & 11 & 12 & 10 & 20 & 63 \\
\hline 8 & Average & B & 12 & 10 & 10 & 10 & 15 & 57 \\
\hline 9 & Average & B & 14 & 12 & 10 & 10 & 12 & 58 \\
\hline 10 & Average & B & 11 & 10 & 11 & 11 & 13 & 56 \\
\hline
\end{tabular}

From the above table, cumulatively, we can see that out of ten students, seven students fell into average category while another three students fell into good category. Elaborated below is each indicator of writing opinion piece together with student's sample work.

\section{a. Focus}

In terms of focus as one of the elements in wiring opinion piece in a newspaper, some students fail to maintain focus on their opinion writing. According to the above table, four 
students are in fair category with regards to focus. They may fail to build focus on their topic. While other five students are in fairly good category with regards to focus. Student may lose or may exhibit major lapses in focus on topic/subject. Only one student managed to be in good category with regards to focus. S/he may have made small shift in focus on their topic. Below is an example of a good use of focus in students' writing:

S6 :

The earth began to age because humans themselves in a way like cutting down trees carelessly so that it creates thin air that is good for us. While another impact caused is there is less water absorption when it rains that it triggers flood. Another factor of natural flood disaster is humans littering which make the environment dirty. Some factories throw their wastes into rivers or the sea so that it can damage the marine ecosystem and make the environment dirty and polluted that are some examples of what humans do that makes our earth grow old so that it can cause disasters such as what I say is flooding, air pollution and others in part.

The above piece of opinion has good focus since the writer mentions several examples that make the planet earth slowly damaged. He tries to exemplify one by one the causes and the impact that humans make to the earth.

\section{b. Ethos}

In this study, in terms of ethos as one of the elements in wiring opinion piece in a newspaper, five students are scored fairly good in building ethos which means that most of the writer's arguments and evidence is strong with evident quality of sources. While other four students are categorized fair in terms of ethos. This means that four students arguments and evidence are uneven in quality, though overall they are adequate. Source quality appears questionable. However, one student is scored good in terms of ethos. This means that s/he uses strong arguments and introduces evidence to show high quality sources. Below is an example of a good use of ethos in opinion writing:

S1:

Today, there are many young people who do not pay attention to the nature/manners. They like not knowing good behavior or bad, even though manners can help to form a character from someone. In this millennial era young people also pay less attention to their politeness to older people, in fact there are also some of them who are very brave to swear or say dirty to others.

The expression in bold shows that the writer has provided evidence of what happens amongst young people. He depicted what portrays in a teenager's life especially in some cities in Indonesia. Therefore, this piece of opinion is considered good.

\section{c. Pathos}

With regards to pathos (the means of persuasion that appeals to the emotions of an audience), five students are scored fairly good which means that most of the writer's appeals to the readers' values and beliefs are effective. While four students are categorized fair in terms of pathos. This means that the students still lack ability to express their emotions in their writing. In the meantime, one student is scored good in terms of pathos which means that the writer uses effective strategies to appeal to the reader's values and beliefs. Below is an example of good use of pathos by student 10 : 
"Despite the environment is very important for life, both human and life around. With environmental cleanliness that memadiai all life while awake and safe. Let us see that there are many irregularities in preserving the environment, such as natural disasters due to environment that is not guarded, as we know the consequences of human unconsciousness on the environment makes nature angry."

The clause in bold expresses that the writer tries to bring the readers into her own feeling in which she feels that the nature's damage is due to human intervention.

\section{d. Logos and Research}

"Logos" is the consistency and clarity of an argument as well as the logic of evidence and reasons. When it comes to logos (logos is a literary device that can be described as a statement, sentence, or argument used to convince or persuade the targeted audience by employing reason or logic) and research is the reference where the writer cites and refers to to bring up ideas and facts. Finding facts can be daunting for some writers as it requires attention to details.

In this study, three students are classified good, while another seven are classified average. Good means that the writer's organization and logic is strong. The writing uses citation, both in-text and on reference page or notes. Below is an example of good use of Logos and Research:

S6 :

As for the sanctions contained in Law No. 35 of 2009 concerning drugs, sanctions for punishments of those found carrying drugs above 5 grams, could be threatened with the death penalty, the enactment of the new Narcotics Law, a number of drug users and dealers if caught carrying narcotics under 5 grams then threatened with a sentence of 4 to 5 years in prison. And a minimum sentence of 4 years with a 500 million fine is included, if you cannot afford it, then the sentence will be added to 2 years.

The bold clause clearly shows that the writer used a reference to strengthen her argument.

\section{e. Writing Fluency}

Lastly, in terms of writing fluency, one student is categorized as good since her writing is clear and concise. While other five students are categorized as fairly good as There are a few surface errors but they are not distracting. Writing is clear and concise. While other four students are categorized fair since there are surface errors which sometimes make it difficult to understand the writer's message and their writing is generally unclear and/or wordy. Below is an example of a good writing fluency:

S7:

The rise of promiscuity among teenagers lately has become a common thing for some people, it is based on the opinion of some teenagers who think that it is not cool if you do not do it.

\section{Results of Interview.}

To investigate students' problem in writing an opinion piece, we applied semi-structured interview. Below is the quotes of some of the interview results with the students.

\begin{tabular}{ll}
\hline Question 1 : & $\begin{array}{l}\text { "Did you have any difficulty in starting to write an } \\
\text { opinion piece?" }\end{array}$ \\
\hline
\end{tabular}




\begin{tabular}{|c|c|c|}
\hline Responses & : S1: & $\begin{array}{l}\text { "Yes, it was hard to begin writing and put your pen } \\
\text { to the paper. I found it difficult to think of what to } \\
\text { write." }\end{array}$ \\
\hline & S3: & $\begin{array}{l}\text { "To start writing is difficult because I am not used } \\
\text { to writing an article". }\end{array}$ \\
\hline Question 2 & : & $\begin{array}{l}\text { "How did you finally come up with an idea of a } \\
\text { topic in your writing?" }\end{array}$ \\
\hline \multirow[t]{2}{*}{ Responses } & : S5: & $\begin{array}{l}\text { "It took me almost twenty minutes to finally be able } \\
\text { to come up with an idea. I think about the } \\
\text { surrounding phenomenon" }\end{array}$ \\
\hline & S7: & $\begin{array}{l}\text { "I think what I like to observe in my daily life. That's } \\
\text { how I come u with an idea of a topic" }\end{array}$ \\
\hline Question 3 & $:$ & $\begin{array}{l}\text { "What is the most difficult part when it comes to } \\
\text { writing in general? }\end{array}$ \\
\hline \multirow[t]{2}{*}{ Responses } & : S2: & $\begin{array}{l}\text { "Writing requires good knowledge of grammar, } \\
\text { punctuation, spelling, etc. I am not yet good at those } \\
\text { aspects of writing because I am still learning" }\end{array}$ \\
\hline & S4: & $\begin{array}{l}\text { "Writing in English must be up to the standard of } \\
\text { good English. So, I have to check and check the } \\
\text { vocabulary over and over again to make sure my } \\
\text { words are appropriate and suitable." }\end{array}$ \\
\hline Question 4 & $:$ & $\begin{array}{l}\text { From the five aspects of opinion piece, such as } \\
\text { focus, ethos, pathos, logos and research, and writing } \\
\text { fluency, which do you think gets in your way in } \\
\text { writing, and why? }\end{array}$ \\
\hline \multirow[t]{2}{*}{ Responses } & S6: & $\begin{array}{l}\text { "I think to keep focus on my writing is difficult. } \\
\text { Because ideas can change as I tried to elaborate on } \\
\text { my thoughts." }\end{array}$ \\
\hline & S9: & $\begin{array}{l}\text { "To me, pathos is difficult because we are asked to } \\
\text { touch someone's feeling with our writing, and this } \\
\text { is difficult." }\end{array}$ \\
\hline Question 5 & $:$ & $\begin{array}{l}\text { "Did you follow the steps in writing such as } \\
\text { planning, drafting, writing and revising?" }\end{array}$ \\
\hline \multirow[t]{2}{*}{ Responses } & S6: & "I did not really follow it" \\
\hline & S8: & $\begin{array}{l}\text { "I just wrote everything that came across my mind } \\
\text { with minimum revision" }\end{array}$ \\
\hline
\end{tabular}


The above interview excerpts revealed that some students did not follow the steps in writing and some indicators in writing an opinion piece. Some students fail to make revisions to publishable quality. This has lead to the poor quality of their writing.

\section{Conclusion}

This research has lead us to discover the extent of students' ability in writing opinion column pieces. On average, students' ability is categorized "average" classified from the five indicators of focus, ethos, pathos, logos and research and writing fluency. From the text analysis, it was revealed that some students have difficulties in inputting some quotes or resources. In fact, resources are an important part in writing an opinion. Thus, it can be summarized that students were poor in maintaining logos and research. Students were also low in terms of focus. They were not able to maintain focus as they tend to shift the focus from one topic of discussion to another. Some of the titles of students' opinion are less interesting. The first paragraph was considered not catching attention. It is suggested that future studies may involve bigger number of students in the form of Classroom Action Research. It is expected that by giving students several meetings to draft, plan and edit their writing, their work would have been improved.

\section{References}

Anonymous. (n.d.). Writing Opinion Essays. Retrieved April 21, 2020 from: https://www.murphycentre.ca/trudy/English3201/HandoutWritingtheOpinionEssay.ht $\underline{\mathrm{ml}}$

Ashewmaker. (n.d.). Journalism Article Rubric. Retrieved April 20, 2020 from https://www.rcampus.com/ rubricshowc.cfm?code=KX39B5C\&sp=true

Belkhir, A. \& Benyelles, R. (2017). Identifying EFL Learners Essay Writing Difficulties and Sources: A Move towards Solution The Case of Second Year EFL Learners at Tlemcen Universi. International Journal of Learning, Teaching and Educational Research. Vol. 16, No. 6, pp. 80-88

Damiani, M.F., Alves, C.V.P., Frison, L.M.B., \& Machado, R.F. (2011). Diagnosis and analysis of academic writing problems of students of pedagogy. Language and Teaching Journal. 14, (2), 455-478

Finding Your Focus. (n.d.). Retrieved April 20, 2020, from https://www.vanderbilt.edu/writing/wp-content/uploads/sites/164/2013/06/Focus.pdf

Hall, D. (1988). Writing well. Little, Brown and Company, Boston.

Haider, G. (2012). An insight into difficulties faced by Pakistani student writers: Implications for teaching of writing. Journal of Educational and Social Research, 2 (3), 17-27.

Hyland, K. (2003). Second language writing. Ernst Klett Sprachen

Jacobs, \& L, H. (1981). Testing esl composition: A practical approach. English composition program. Newbury House, Massechautes 
Opinion piece. (n.d.). In Wikipedia. Retrieved May 30, 2020, from https://en.wikipedia.org/wiki/Opinion_piece

Ramage, J. D., Bean, J.C., Johnson, J. (2016). Writing arguments: a rhetoric with readings. Pearson Education.

Richard, J. C. \& Schmidt, R. (2002). Longman dictionary of language teaching and applied linguistics (3rd Ed). Longman. p.529.

Roen, D., Glau, G., Maid, B., (2011). The McGraw-Hill Guide: Writing for College, Writing for Life 4th Edition. McGraw-Hill

Shokrpour, N., \& Fallazadeh, M. (2007). "A survey of the students and Interns ${ }^{\text {ee } E F L ~ W r i t i n g ~}$ problems in Shiraz University of Medical Sciences”. Asian EFL Journal. 9(1).

Writing to Convince and Solve Problems Option 1: Opinion Piece. (n.d.). Retrieved April 20, 2020, from utminers.utep.edu/omwilliamson/engl1311/opin.doc 